\title{
Faktor yang Berhubungan dengan Kejadian Stunting pada Baduta di Kelurahan Ampel Kota Surabaya
}

\section{Determinants of Stunted Children Under Two Years Old in Ampel Village, Surabaya}

\author{
Rochana Tsaralatifah ${ }^{1}$
}

\section{ABSTRAK}

Latar Belakang: Stunting adalah kondisi pertumbuhan tinggi badan anak mengalami gangguan dimana tinggi badan tidak sesuai dengan usianya. Stunting merupakan permasalahan yang disebabkan karena multifaktor. Anak yang mengalami stunting sebelum usia 6 bulan, akan mengalami pertumbuhan yang terganggu sehingga terjadi kekerdilan lebih berat menjelang usia dua tahun. Data stunting di provinsi Jawa Timur berdasarkan hasil Riskesdas tahun 2018 tercatat sebesar $32,81 \%$ balita dengan gizi sangat pendek dan pendek. Hal tersebut masih menjadi masalah kesehatan karena masih melebihi standar yang ditetapkan oleh WHO, dimana suatu wilayah dikatakan mengalami masalah gizi akut bila prevalensi bayi stunting sama atau lebih dari $20 \%$. Sementara prosentase bayi pendek di Indonesia saat ini masih lebih dari $29 \%$ dan ditargetkan turun mencapai $19 \%$ pada tahun 2024 . Untuk menurunkan angka stunting perlu diketahui faktor apa saja yang berhubungan dengan kejadian tersebut. Seperti rendahnya frekuensi kunjungan ibu ke posyandu yang berdampak pada rendahnya pengetahuan ibu terkait kesehatan anak.

Tujuan: Mengetahui hubungan antara karakteristik keluarga dan karakteristik responden dengan kejadian stunting pada baduta di RW 06 kelurahan Ampel kota Surabaya.

Metode: Penelitian ini dilakukan di RW 06 kelurahan Ampel kecamatan Semampir mulai dari bulan Desember 2019-Januari 2019. Penelitian ini menggunakan metode observasional analitik dengan desain studi cross sectional dan penarikan sampelnya menggunakan teknik simple random sampling. Populasi yang digunakan dalam penelitian ini adalah seluruh baduta yang bertempat tingggal di RW 06 kelurahan Ampel kota Surabaya. Metode pengumpulan data dengan melakukan pengukuran, wawancara dan analisis data menggunakan uji fisher exact dengan tingkat kepercayaan $95 \%(\alpha=0,05)$

Hasil: Hasil penelitian menunjukkan bahwa tingkat pengetahuan ibu $(p=0,046)$ dan frekuensi datang ke posyandu $(p=0,01)$ merupakan faktor yang berhubungan dengan kejadian stunting. Sedangkan variabel karakteristik keluarga (jumlah anggota keluarga, tingkat pendapatan rumah tangga, tingkat pendidikan ibu) dan karakteristik responden(jenis kelamin, BB lahir, PB lahir, riwayat ASI eksklusif) tidak terdapat hubungan dengan kejadian stunting $(p>0,05)$.

Kesimpulan: : Hasil penelitian menunjukkan pengetahuan dan frekuensi kunjungan posyandu ibu baduta berhubungan dengan kejadian stunting sehingga petugas kesehatan perlu melakukan sosialisasi kepada masyarakat tentang pentingnya kegiatan posyandu dengan adanya sosialisasi tersebut diharapkan dapat menambah pengetahuan ibu terkait kesehatan anak, sehingga dapat meningkatkan frekuensi kunjungan baduta keposyandu.

Kata kunci: baduta, stunting, pengetahuan ibu, kunjungan posyandu

\section{ABSTRACT}

Background: Stunting is a condition of a child's growth disorder where the child's height does not match his age. Stunting is a problem caused by multifactorial. Children who grow stunting before the age of 6 months, will experience growth that is distrupted so that stunted more than severe by the age of two years. East Java province based on the result of Riskesdas in 2018 was recorded at 32,81\% of toddelrs severe stunted and short. It is still a health problem because it still exceeds the standars set by $W H O$, where an area experiences acute nutritional problems if the prevalence of stunting babies is the same or more than 20\%. While the percentage of short babies in Indonesia is still more than 29\% and is targeted to $19 \%$ in 2024. To reduce the number of stunting need to know what factors are associated with the incident. Such as the low frequency of maternal attendance at the neighborhood health services (Posyandu) which has an impact on the low level of maternal knowledge regarding child health.

Objectives: To determine the relationship between family characteristics and the characteristics of respondents with the incidence of stunting in children under two years old in RW 06 Kelurahan Ampel Kota Surabaya.

Methods: This research was conducted in RW 06 Ampel sub-district Semampir sub-district starting from December 2018January 2019. This research was an observational analytic study with cross sectional study design and sampling using a simple random sampling technique. The population used in this study were all children under two years old living in RW 06, 
Ampel, Surabaya. Data collection methods were interview using structured questionnaire. Data was analyzed using the fisher exact test with a confidence level of $95 \%(\alpha=0.05)$

Results: The results showed that the level of maternal knowledge $(p=0.046)$ and the frequency of attendance at the neighborhood health services (Posyandu) ( $p=0.01$ ) were factors related to stunting. While the variable family characteristics (number of family members, household income level, mother's education level) and respondent characteristics (gender, birth weight, birth length, birth history of exclusive breastfeeding) have no relationship with the incidence of stunting $(p>0,05)$.

Conclusions: Knowledge and frequency of attendance at the neighborhood health services (Posyandu) by Children Under Two Years Old mothers were related to stunting incidence. Therefore, health workers need to disseminate information to the public about the importance of Posyandu

Keywords: baduta, stunting, mother's knowledge, Integrated Services Post visit

\author{
*Koresponden: \\ Rochana Tsaralatifah \\ Rochana.tsaralatifah-2018@fkm.unair.ac.id \\ Program Studi Kesehatan Lingkungan, Fakultas Kesehatan Masyarakat, Airlangga University Jl. Mulyorejo, Surabaya \\ Published by Universitas Airlangga and IAGIKMI
}

\section{PENDAHULUAN}

Pemerintah mencanangkan gerakan 1000 Hari Pertama Kehidupan (HPK)yang mana gerakan tersebut merupakan salah satu upaya untuk menurunkan angka stunting. Maksud dari periode 1000 hari yaitu terhitung dari 270 hari selama kehamilan dan 730 hari kehidupan pertama bayi yang dilahirkan. Pada periode tersebut merupakan periode sensitif karena akibat yang ditimbulkan dalam masa ini akan bersifat permanen pada bayi dan tidak bisa di tolerir atau diperbaiki lagi. ${ }^{8}$ Terdapat dua intervensi dalam pembagian kegiatan 1000 HPK yakni intervensi spesifik dan intervensi sensitif. Pembentukan sumber daya manusia (SDM) yang berkualitas dimana difokuskan kepada ibu hamil, bayi kelompok umur 0-6 bulan dan 7- 23 bulan atau sejak masih dalam kandungan sampai berusia 2 tahun merupakan sasaran dari intervensi spesifik. Masa usia 12 - 24 bulan adalah masa rawan dimana balita sering mengalami penyakit yang disebabkan oleh infeksi atau gangguan status gizi, karena di usia tersebut proses peralihan dari bayi menjadi anak sedang di lalui oleh balita. ${ }^{21}$

Stunting adalah kondisi pertumbuhan tinggi badan anak mengalami gangguan dimana tinggi badan anak tidak sesuai dengan usianya. Menurut Kemenkes RI (2015) Stunting atau tubuh pendek merupakan indikator jangka panjang untuk seorang anak yang kekurangan gizi dimana kejadian tersebut merupakan akibat dari tumbuh kembang yang mengalami kegagalan dan kekurangan gizi kronis dimasa lalunya. ${ }^{10}$. Balita dengan tubuh pendek dapat diketahui apabila sudah dapat diukur panjang atau tinggi badannya, kemudian dibandingkan dengan standar baku WHO-MGRS (Multicentre Growth Reference Study) tahun 2005 dan didapatkan hasil nilai $z$-score $<-2$ SD, sedangkan dikatakan sangat pendek apabila hasil z-score<-3 SD. ${ }^{11}$

Datastunting di provinsi Jawa Timur berdasarkan hasil Riskesdas tahun 2018 tercatat sebesar 32,81\% balita dengan gizi sangat pendek dan pendek. Hal tersebut masih menjadi masalah kesehatan karena masih melebihi standar yang ditetapkan oleh WHO, dimana suatu wilayah dikatakan mengalami masalah gizi akut bila prevalensi bayi stunting sama atau lebih dari
20\%. Sedangkan presentase bayi stunting di kota Surabaya pada tahun 2018 sebesar 8,92 \% ( sangat pendek 2,04\% dan pendek sebesar 6,88\%). ${ }^{4}$.Dalam berita Jawa Pos (2019) disebutkan bahwa di Surabaya Utara terdapat dua kecamatan dengan jumlah angka stunting terbanyak yakni kecamatan Kenjeran dan kecamatan Semampir. Kecamatan Semampir tercatat memiliki jumlah kasus stunting sebesar 1.399 anak. Sementara prosentase bayi pendek di Indonesia saat ini masih lebih dari $29 \%$ dan ditargetkan turun mencapai $19 \%$ pada tahun $2024 .^{9}$

Stunting merupakan permasalahan yang disebabkan karena multifaktor. Faktor individu maupun faktor keluarga dapat menyebakan terjadinya stunting. Dampak buruk yang akan timbul dari kejadian stunting dalam jangka pendek adalah terganggunya kecerdasan intelektual, perkembangan otak, fisik maupun gangguan metabolisme tubuh pada anak. Anak yang mengalami stunting sebelum usia 6 bulan, akan mengalami pertumbuhan yang terganggu sehingga terjadi kekerdilan lebih berat menjelang usia dua tahun. Sedangkan dampak jangka panjang akibat stunting yaitu besarnya resiko terkena penyakit tidak menular, kesehatan yang memburuk, intelektual atau kecerdasan dan prestasi pendidikan di masa anak - anak menjadi buruk.

Ampel merupakan salah satu kelurahan yang berada di Kecamatan Semampir. Berdasarkan data puskesmas diketahui RW 06 merupakan RW dengan angka stunting terbanyak di kelurahan tersebut yaitu sebesar 19 balita dari 57 balita dan sebesar 6 baduta dari 26 baduta. Tujuan dilakukannya penelitian ini yaitu untuk mengetahui hubungan antara variabel karakteristik keluarga dan karakteristik responden dengan kejadian stunting pada baduta di RW 06 Kelurahan Ampel kota Surabaya sehingga nantinya angka stunting dapat diturunkan.

\section{METODE}

Penelitian ini dilakukan di RW 06 kelurahan Ampel kecamatan Semampir kota Surabaya mulai bulan Desember 2019 sampai Januari 2020. Penelitian ini menggunakan metode observasional analitik dengan 
desain studi cross sectional dan penarikan sampelnya menggunakan teknik simple random sampling yaitu untuk mengetahui hubungan antara variabel karakteristik keluarga dan karakteristik responden dengan kejadian stunting pada baduta di RW 06 Kelurahan Ampel kota Surabaya. Populasi dalam penelitian ini adalah seluruh baduta yang bertempat tingggal di Rw 06 kelurahan Ampel kota Surabaya dengan jumlah populasi sebesar 26 responden. Kriteria inklusi dalam penelitian ini yaitu responden yang bersedia dan hadir saat dilakukan penelitian.

Berdasarkan kriteria tersebut kemudian dilakukan perhitungan sampel dengan hasil sampel sebesar 19 responden yang mana variabel dependen penelitian ini adalah kejadian stunting, sedangkan variabel independen dalam penelitian ini adalah adalah karakteristik responden (Jenis kelamin yaitu baduta lakilaki maupun perempepuan, BB lahir yaitu berat badan pertama bayi yang di ukur setelah bayi lahir,PB lahir yaitu panjang badan pertama bayi yang di ukur setelah bayi lahir, riwayat ASI ekslusif yaitu baduta hanya menerima ASI dari ibu tanpa cairan atau tambahan makanan padat lain selama 6 bulan) dan karakteristik keluarga responden (pendapatan orang tua yaitu jumlah uang yang diterima orang tua dari hasil pekerjaannya selama satu bulan, pendidikan orang tua yaitu tingkat pendidikan yang ditempuh mulai dari awal sampai pendidikan terakhir saat dilakukan penelitian, pengetahuan gizi ibu yaitu segala sesuatu tentang makanan, berhubungan dengan kesehatan optimal yang di ketahui ibu dan jumlah anggota keluarga baduta yaitu seberapa banyak anggota keluarga yang tinggal bersama dengan baduta serta frekuensi kedatangan ibu baduta ke posyandu yaitu seberapa sering ibu dan baduta datang ke posyandu).
Data yang dikumpulkan adalah jenis data primer dan data skunder sebagai penunjang. Data primer didapatkan dari hasil wawancara menggunakan kuesioner kepada ibu baduta. Panjang badan baduta diperoleh dengan melakukan pengukuran dengan menggunakan length board.

Penelitian ini telah mendapatkan persetujuan dari komisi etik Fakultas Kesehatan Masyarakat Universitas Airlangga dengan nomor 1769- KEPK. Analisis data untuk melihat hubungan variabel dan besar resiko (OR) menggunakan uji chi-square dan jika salah satu uji chi-square tidak terpenuhi maka selanjutnya dilakukan uji fisher exact dengan tingkat kepercayaan $95 \%(\alpha=0,05)$.

\section{HASIL DAN PEMBAHASAN}

Hubungan Antara Karakteristik Responden (Jenis Kelamin, BB Lahir Baduta, PB Lahir Baduta, Riwayat ASI Eksklusif ) dengan Kejadian Stunting

Pada tabel 1 menunjukkan karakteristik responden yaitu berdasarkan jenis kelamin, BB lahir baduta, PB lahir baduta, dan riwayat ASI eksklusif. Tabel 1 dapat diketahui bahwa baduta berjenis kelamin laki- laki (40\%) lebih banyak mengalami stunting dibandingkan baduta perempuan (22,2\%). Setelah dilakukan uji fisher Exact diperoleh $p>0,05$ atau $p=0,628$ yang berarti antara jenis kelamin laki - laki maupun perempuan tidak ada hubungan dengan kejadian stunting. Hasil ini sesuai penelitian oleh Masrul (2019) bahwa hasil tersebut menunjukkan tidak adanya hubungan yang bermakna antara jenis kelamin anak dengan kejadian stunting. Sejalan dengan penelitian yang dilakukan oleh Ningrum \& Utami, (2017) mengatakan tidak ada hubungan antara jenis kelamin dengan perkembangan balita.

Tabel 1. Hubungan Antara Karakteristik Responden (Jenis Kelamin, BB Lahir Baduta, PB Lahir Baduta, Riwayat ASI Eksklusif ) dengan Kejadian Stunting.

\begin{tabular}{|c|c|c|c|c|c|c|c|c|}
\hline \multirow[t]{2}{*}{ Variabel } & \multicolumn{2}{|c|}{ Stunting } & \multicolumn{2}{|c|}{ Normal } & \multicolumn{2}{|c|}{ Total } & \multirow{2}{*}{$\begin{array}{c}P \\
\text { value }\end{array}$} & \multirow{2}{*}{$\begin{array}{c}\text { OR } \\
(95 \% \mathrm{Cl})\end{array}$} \\
\hline & $\mathbf{n}$ & $\%$ & $\mathbf{n}$ & $\%$ & $\mathbf{n}$ & $\%$ & & \\
\hline \multicolumn{9}{|l|}{ JenisKelamin } \\
\hline Laki- laki & 4 & 40 & 6 & 60 & 10 & 100 & & $2,333(0,310-17,545)$ \\
\hline Perempuan & 2 & 22,2 & 7 & 77,8 & 9 & 100 & 0,628 & \\
\hline \multicolumn{9}{|l|}{ BBLahir } \\
\hline BBLR(< 2500 gram) & 0 & 0 & 2 & 100 & 2 & 100 & & $0,647(0,455-0,919)$ \\
\hline Normal (>2500 gram) & 6 & 35,3 & 11 & 64,7 & 17 & 100 & 1 & \\
\hline \multicolumn{9}{|l|}{ PBLahir } \\
\hline$<48 \mathrm{~cm}$ & 2 & 50 & 2 & 50 & 4 & 100 & & $3,333(0,427-26,039)$ \\
\hline$\geq 48 \mathrm{~cm}$ & 4 & 26,7 & 11 & 73,3 & 15 & 100 & 0,320 & \\
\hline \multicolumn{9}{|l|}{ Riwayat ASI Eksklusif } \\
\hline Tidak ASI Eksklusif & 2 & 25 & 6 & 75 & 8 & 100 & & $0,889(0,113-7,016)$ \\
\hline ASI Eksklusif & 4 & 36,36 & 7 & 63,64 & 11 & 100 & 1 & \\
\hline
\end{tabular}

Pada tabel 1 menunjukkan variabel berat badan lahir sebagian besar baduta stunting lahir dengan BB normal. Berdasarkan hasil uji BB lahir dengan kejadian stunting menunjukkan bahwa tidak ada hubungan antar keduanya $(p>0,05)$. Penelitian ini sejalan dengan Masrul (2019) di kabupaten Pasaman Sumatra Barat bahwa berat badan lahir bayi pada penelitian ini tidak menunjukkan hubungan yang bermakna dengan kejadian stunting pada baduta. ${ }^{13}$.
Karena sebagian besar responden lahir dengan berat badan normal dan hanya dua responden yang lahir dengan berat badan rendah. Hal tersebut dapat menjadi faktor yang menyebabkan tidak adanya hubungan yang bermakna antar keduanya. Selain itu terdapat banyak faktor yang menyebabkan terjadinya stunting pada baduta seperti asupan gizi yang kurang dan lain sebagainya. Berbeda dengan penelitian yang dilakukan oleh Setiawan, Machmud, \& Masrul (2018) dimana hasil 
menunjukkan antara BB lahir dengan kejadian stunting pada anak usia 24-59 bulan. ${ }^{20}$ Penelitian lain oleh Anisa ( 2012) juga mengatakan terdapat hubungan antara BB lahir dengan kejadian stunting pada balita, dimana balita dengan BB lahir rendah beresiko terjadi stunting lebih besar dari pada lahir dengan berat badan normal. ${ }^{2}$

Berdasarkan tabel 1, sebesar $50 \%$ baduta dengan panjang badan lahir < $48 \mathrm{~cm}$ lebih banyak mengalami stunting di bandingkan dengan baduta yang lahir dengan panjang lahir $\geq 48 \mathrm{~cm}(26,7 \%)$. Hasil uji fisher exact menunjukkan bahwa tidak ada hubungan yang bermakna antara PB lahir dengan kejadian stunting pada baduta $(p=0,320$ atau $p>0,05)$. Hasil ini sejalan dengan penelitian yang dilakukan oleh Dasantos (2019) yang menunjukkan bahwa antara panjang badan lahir tidak terdapat hubungan dengan resiko terjadinya stunting pada balita di kabupaten Pidie. Akan tetapi, hal ini berbeda dengan penelitian yang dilakukan oleh Nadhiroh, Siti Rahayu; Ni'mah, (2010) di puskesmas Tanah Kali Kedinding Surabaya bahwa terdapat hubungan antara PB lahir anak dengan kejadian stunting. ${ }^{14}$. selain itu penelitian yang dilakukan oleh Wellina, Kartasurya, \& Rahfilludin (2016) bahwa baduta yang lahir dengan panjang badan lahir pendek mempunyai resiko 6,29 kali lebih besar terjadi stunting dari pada baduta lahir dengan panjang badan normal. Karena pada penelitian tersebut, baduta lahir dengan PB pendek lebih banyak dibandingkan dengan panjang badan normal. ${ }^{22}$.

Pada variabel riwayat ASI, sebagian besar baduta memiliki riwayat ASI eksklusif. Setelah dilakukan uji fisher exact di dapatkan bahwa tida kada hubungan antara riwayat ASI ekslusif dengan kejadian stunting $(p=1)$. Penelitian ini sesuai dengan Anisa (2012) di Kalibaru bahwa pemeberian ASI eksklusif dengan kejadian stunting di Kalibaru tidak terdapat hubungan. ${ }^{2}$. Berbeda dengan penelitian yang dilakukan oleh Kusuma \& Nuryanto (2013),Fitri, (2018) dan Nadhiroh, Siti Rahayu; Ni'mah, (2010) bahwa adanya hubungan signifikan antara riwayat ASI Ekslusif dengan kejadian stunting. Karena pada penelitian tersebut sebagian besar kelompok kasus (stunting) tidak memiliki riwayat ASI eksklusif sehingga hal tersebut dapat menjadi salah satu faktor adanya hubungan antar keduanya. ${ }^{12,14}$. Selain itu pada penelitian ini jumlah sampel yang

Pada Tabel 2 tingkat pendapatan rumah tangga responden, sebagian besar memiliki pendapatan rendah yakni dibawah UMK yang telah di tetapkan kota Surabaya (Rp. 4.200.00). Pendapatan rumah tangga padabaduta stuntinglebih banyak yang berpenghasilan rendah dari pada baduta yang tidak stunting. Setelah dilakukan uji fisher exact dengan tingkat kepercayaan $95 \%(\alpha=0,05)$ menunjukkan bahwa tingkat pendapatan rumah tangga bukan menjadi faktor penyebab terjadinya stunting $(p>0,05)$. Hasil penelitian ini berbeda dengan penelitian yang telah dilakukan oleh Ngaisyah, (2015) yang berlokasi di Gunung Kidul bahwa kelompok stunting yang pendapatan keluarganya dibawah UMK lebih banyak, sedangkan yang berpenghasilan di atas UMK hanya sedikit. ${ }^{15}$. Penelitian oleh Phyo, Keiwkarnka, \& Mongkolchati (2014) di kota Magway Myanmar menunjukkan bahwa pendapatan keluarga yang rendah menjadi salah satu faktor penyebab terjadinya stunting dihasilkan sedikit, sehingga akan berpengaruh saat dilakukan hasil uji. Meskipun tidak terdapat hubugan antar keduanya, perlu dilakukan penyuluhan kepada ibu maupun calon ibu tentang pentingnya ASI eksklusif untuk tumbuh kembang bayinya. ASI eksklusif adalah proses pemberian ASI tanpa tambahan makanan apapun mulai dari bayi berusia 0-6 bulan. ASI merupakan nutrisi penting yang diperlukan untuk tumbuh kembang bayi.

Hubungan Antara Karakteristik Keluarga Responden (Banyaknya Jumlah Anggota Keluarga, Tingkat Pendapatan Rumah Tangga, Tingkat Pendidikan Ibu, Tingkat Pengetahuan Gizi Ibu Dan Frekuensi Kehadiran Baduta Keposyandu) dengan Kejadian Stunting di RW 06 Kelurahan Ampel Kota Surabaya

Tabel 2 menunjukkan hubungan antara karakteristik keluarga responden (banyaknya jumlah anggota keluarga, tingkat pendapatan rumah tangga, tingkat pendidikan ibu, tingkat pengetahuan gizi ibu dan frekuensi kehadiran baduta keposyandu) dengan kejadian stunting.

Pada karakteristik jumlah anggota rumah tangga dalam tabel 2, sebagian besar responden memiliki lebih dari 4 anggota rumah tangga yaitu sebesar 13 responden. Untuk jumlah anggota rumah tangga baduta stunting memiliki proporsi yang sama, yakni baduta dengan keluarga lebih dari empat sejumlah 3 responden dan baduta dengan jumlah keluarga kurang dari empat sejumlah 3 responden. Setelah dilakukan uji menggunakan fisher exact dengan tingkat kemaknaan 95\% $(\alpha=0,05)$ didapatkan hasil $p>0,05(p=$ 0,320 ) yang berarti tidak ada hubungan bermakna antara banyaknya nggota rumah tangga baduta dengan kejadian stunting. Sesuai dengan penelitian yang dilakukan oleh Nadhiroh, Siti Rahayu; Ni'mah (2010) di Tanah Kali Kedinding Surabaya bahwa jumlah anggota keluarga bukan merupakan faktor penyebab terjadinya stunting. Hal ini dikarenakan kejadian stunting disebabkan oleh multifaktor, tidak mutlak dipengaruhi oleh jumlah anggota keluarga. ${ }^{14}$. Dukungan keluarga dalam memberikan gizi seimbang juga dapat mempengaruhi status gizi baduta. Bila jumlah anggota keluarga banyak namun asupan gizi dan nutrisi terpenuhi, maka kejadian stunting pun tidak terjadi pada baduta.

pada baduta. ${ }^{18}$. Penelitian lain oleh Setiawan et al.(2018) menunjukkan antara kejadian stuntingdengan pendapatan keluarga terdapat hubungan yang bermakna. ${ }^{20}$. Status ekonomi rendah atau penghasilan yang rendah di sebuah keluarga memiliki pengaruh yang cukup besar terhadap kejadian kurus dan pendek pada anak. Namun, pada penelitian ini, pendapatan keluarga tidak berhubungan dengan kejadian stunting di karenakan mayoritas penduduk di wilayah tersebut berpenghasilan menengah ke bawah. Sebanyak 14 responden dari 19 responden pendapatan keluarga di dominasi oleh keluarga dengan pendapatan di bawah UMK yang ditetapkan. Hal tersebut dapat menjadi faktor tidak adanya hubungan antar keduanya.

Pendidikan ibu menurut tabel 2 yaitu sebagian besar ibu baduta berpendidikan rendah yaitu sejumlah 16 responden. Semua baduta dengan stunting memiliki 
ibu dengan tingkat pendidikan yang rendah. Hasil analisis uji fisher exact menunjukkan bahwa pendidikan ibu tidak menjadi faktor penyebab terjadinya stunting pada baduta. Penelitian ini sesuai dengan penelitian yang dilakukan oleh Anindita,Putri (2012)dan Aisyah et al. (2019) bahwa tidak terdapat hubungan antara tingkat pendidikan ibu dengan kejadian stunting pada balita. ${ }^{1,19}$. Akan tetapi penelitian ini berbeda dengan penelitian yang dilakukan oleh Farah Okky Aridiyah dan Ninna Rohmawati (2015) bahwa hasil penelitian di dapatkan adanya hubungan yang bermakna antara tingkat pendidikan ibu dengan kejadian stunting pada anak balita, baik di pedesaan maupun diperkotaan ${ }^{5}$ Penelitian oleh Anisa, (2012)di dapatkan bahwa pada ibu yang berpendidikan rendah memiliki kecendurungan balita denganstuntinglebih banyak terjadi. Tingkat pendidikan ibu kemungkinan dapat menjadi faktor penyebab terjadinya stunting pada anak. ${ }^{2}$. Ibu dengan pendidikan tinggi akan lebih banyak pengetahuannya dibandingkan dengan ibu yang berpendidikan rendah. Sehingga ibu yang berpendidikan tinggi dapat mengurangi kejadian stunting. Akan tetapi hal tersebut tidak akan sejalan apabila pola asuh ibu terhadap anaknya masih kurang baik. Pola asuh dipengaruhi oleh banyak faktor antara lain, jumlah anak atau anggota dalam keluarga, pekerjaan ibu, latar belakang pendidikan ibu dan lain sebagainya. Pola asuh setiap ibu pada anaknya berbeda- beda hal tersebut dapat mempengaruhi status gizi pada anak. Penelitian oleh Reed dkk tahun 1996 dalam Anindita, Putri (2012) melaporkan bahwa tidak adanya hubungan antar pendidikan ibu dengan status gizi pada anak dan penelitian tersebut menemukan bahwa para ibu yang mempunyai pendidikan tinggi bekerja diluar rumah tidak dapat secara bersamaan memastikan status gizi anaknya. Hal tersebut dapat memungkinkan terjadinya stunting pada anak. ${ }^{19}$

Tabel 2. Hubungan Antara Karakteristik Keluarga Responden dengan Kejadian Stunting di RW 06 Kelurahan Ampel Kota Surabaya.

\begin{tabular}{|c|c|c|c|c|c|c|c|c|}
\hline \multirow[t]{2}{*}{ Variabel } & \multicolumn{2}{|c|}{ Stunting } & \multicolumn{2}{|c|}{ Normal } & \multicolumn{2}{|c|}{ Total } & \multirow[t]{2}{*}{$\mathbf{P}$} & \multirow[t]{2}{*}{ OR (95\%) Cl } \\
\hline & $\mathrm{n}$ & $\%$ & $\mathrm{n}$ & $\%$ & $\mathrm{~N}$ & $\%$ & & \\
\hline \multicolumn{9}{|l|}{ Banyak anggota Rumah Tangga } \\
\hline$\leq 4$ & 3 & 50 & 3 & 50 & 6 & 100 & & \\
\hline$>4$ & 3 & 23,08 & 10 & 76,92 & 13 & 100 & 0,320 & $3,333(0,427-26,039)$ \\
\hline $\begin{array}{l}\text { Tingkat Pendapatan Rumah } \\
\text { Tangga }\end{array}$ & & & & & & & & \\
\hline Rendah (< UMK kota Surabaya & 4 & 28,57 & 10 & 71,43 & 14 & 100 & & \\
\hline Rp. 4.200.000) & & & & & & & 1 & $0,600(0,071-5,059)$ \\
\hline $\begin{array}{l}\text { Tinggi (> UMK kota Surabaya Rp. } \\
4.200 .000 \text { ) }\end{array}$ & 2 & 40 & 3 & 60 & 5 & 100 & & \\
\hline \multicolumn{9}{|l|}{ Tingkat Pendidikan ibu } \\
\hline Pendidikan Rendah & 6 & 37,5 & 10 & 62,5 & 16 & 100 & & \\
\hline Pendidikan Tinggi & 0 & 0 & 3 & 100 & 3 & 100 & 0,628 & $2,333(0,310-17,545)$ \\
\hline \multicolumn{9}{|l|}{ Tingkat pengetahuangizilbu } \\
\hline Baik & 1 & 12,5 & 7 & 87,5 & 8 & 100 & 0,046 & $0,091(0,009-0,880)$ \\
\hline Kurang & 5 & 45,45 & 6 & 54,55 & 11 & 100 & & \\
\hline \multicolumn{9}{|l|}{ Frekuensi ke posyandu } \\
\hline Rutin & 1 & 7,14 & 13 & 92,86 & 14 & 100 & & \\
\hline Tidak & 5 & 100 & 0 & 0 & 5 & 100 & 0,01 & $0,071(0,011-0,472)$ \\
\hline
\end{tabular}

Berdasarkan tabel 2 tingkat pengetahuan gizi ibu baduta di dapatkan bahwa mayoritas ibu memiliki tingkat pengetahuan yang kurang tentang gizi. Setelah dilakukan uji fisher exact, hasil menunjukkan bahwa terdapat hubungan yang signifikan antara pengetahuan gizi ibu dengan kejadian stunting pada baduta $(p=$ 0,046 ) dengan OR sebesar 0,091 . Artinya baduta yang memiliki ibu dengan pengetahuan gizi rendah beresiko 0,091 kali mengalami stunting. Sesuai dengan penelitian yang dilakukan oleh Olsa, Sulastri, \& Anas, (2018) di kota Padang antara pengetahuan ibu dengan kejadian stunting terdapat suatu hubungan yang signifikan. ${ }^{17}$ Penelitian lain dilakukan oleh Nadhiroh, Siti Rahayu; Ni'mah (2010) bahwa pengetahuan ibu merupakan salah satu faktor penyebab kejadian stunting pada balita. ${ }^{14}$. Pengetahuan adalah hasil tahu terhadap suatu objek yang telah dilakukan pengindraan oleh seseorang. Pada manusia, mata dan telinga adalah alat indra yang paling banyak menangkap atau memperoleh informasi. Pengetahuan secara kognitif merupakan domain yang penting dalam membentuk tindakan seorang (Notoatmodjo,2012 dalam Olsa et al., 2018). ${ }^{17}$. Seorang ibu dengan pengetahuan yang baik tentang gizi dapat menurunkan kejadian stunting pada anak. la mampu memberikan nutrisi baik yang diperlukan sang anak untuk tumbuh kembangnya. Informasi atau pengetahuan tentang gizi dapat diperoleh dari mana saja. Dapat berasal dari tenaga kesahatan secara langsung saat melakukan penyuluhan, dari internet maupun dari buku.

Tabel 2 menunjukkan bahwa dari 19 responden, sejumlah 14 keluarga baduta rutin datang ke posyandu dan sebesar 5 keluarga baduta tidak rutin datang keposyandu. Setelah dilakukan uji fisher exact,di dapatkan bahwa adanya hubungan antara frekuensi keluarga datang keposyandu dengan kejadian stunting pada baduta dengan OR sebesar 0,071. Artinya baduta dengan frekuensi datang ke posyandu yang rendah beresiko 0,071 kali mengalami stunting. Pada penelitian yang dilakukan oleh Destiadi, Nindya, \& Sumarmi, (2015) 
mengatakan bahwa faktor lain penyebab stunting yang dianalisa adalah frekuensi terhadap kunjungan posyandu dan riwayat kenaikan berat badan. Dengan nilai $(p<0,05)$ menunjukkan bahwa fekuensi kunjungan ke posyandu dan kenaikan berat badananak merupakan faktor resiko terhadap kejadian stunting. ${ }^{3}$. Posyandu merupakan salah satu pusat kegiatan masyarakat, dimana masyarakat dapat memperoleh pelayanan kesehatan maupun keluarga berencana. Selain itu, posyandu dapat juga dimanfaatkan sebagai sarana saling tukar pendapat dan pengalaman serta bermusyawarah antar anggota masyarakat maupun petugas kesehatan untuk memecahkan masalah yang dihadapi masyarakat. Posyandu merupakan tempat untuk melakukan monitoring status gizi dan pertumbuhan anak yang sangat tepat sehingga dengan datangnya anak ke posyandu akan dilakukan pengukuran tingkat pertambahan berat badan serta tinggi badan secara rutin dalam setiap bulannya. ${ }^{3}$. Frekuensi kehadiran di posyandu yang rutin, sangat berpengaruh terhadap pemantauan status gizi, serta ibu baduta yang datang ke posyandu akan memperoleh informasi terbaru tentang kesehatan maupun gizi yang bermanfaat untuk pola hidup sehat. Berbeda dengan baduta yang tidak pernah hadir dalam posyandu, ia akan sulit untuk dilakukan monitoring terhadap tumbuh kembangnya.

Begitu pula dengan ibu ataupun keluarga yang tidak pernah atau jarang hadir dalam kegiatan posyandu, pengetahuan yang ia dapatkan akan lebih sedikit bila dibandingkan dengan ibu atau keluarga baduta yang sering datang keposyandu. Oleh karena itu, kemungkinan ibu atau keluarga yang tidak pernah atau jarang datang ke posyandu resiko baduta akan mengalami stunting lebih besar dibandingkan dengan ibu atau keluarga baduta yang sering datang ke posyandu.

\section{KESIMPULAN}

Terdapat dua karakterisitik keluarga yang menunjukkan adanya hubungan dengan kejadian stunting di RW 06 kelurahan Ampel, yaitu pada tingkat pengetahuan ibu dan frekuensi kunjungan ke posyandu . Setelah dilakukan analisis, pengetahuan ibu yang rendah dan kunjungan posyandu yang tidak rutin secara tidak langsung merupakan penyebab terjadinya stunting pada baduta. Untuk itu petugas kesehatan perlu melakukan sosialisasi maupun penyuluhan kepada masyarakat tentang pentingnya kegiatan posyandu yang mana dapat menambah dan meningkatkan pengetahuan ibu terkait kesehatan anak. Sehingga kasus stunting di RW 06 dapat mengalami penurunan.

\section{ACKNOWLEDGEMENT}

Ucapan terimakasih kepada dinas kesehatan kota Surabaya, kepada camat Semampir beserta jajarannya, kepada lurah Ampel dan ketua RW 06 serta temanteman yang telah ikut membantu dalam penelitian ini.

\section{REFERENS}

1. Nadhiroh, Siti Rahayu; Ni'mah, K. Faktor yang berhubungan dengan kejadian. Media Gizi Indones.1, 13-19 (2010).

2. Ngaisyah, R. D. Hubungan Sosial Ekonomi Dengan Kejadian Stunting pada Balita di Desa Kanigoro, Saptosari Gunung Kidul. J. Med. RespatiX, 65-70 (2015).

3. Phyo, S. W., Keiwkarnka, B. \& Mongkolchati, A. Factors related to stunting status of the children aged uncer two years in Magway Township, Myanmar. J. Public Heal. Dev.12, 315 (2014).

4. Setiawan, E., Machmud, R. \& Masrul, M. FaktorFaktor yang Berhubungan dengan Kejadian Stunting pada Anak Usia 24-59 Bulan di Wilayah Kerja Puskesmas Andalas Kecamatan Padang Timur Kota Padang Tahun 2018. J. Kesehat. Andalas7, 275 (2018).

5. Putri Anindita. Hubungan Tingkat Pendidikan Ibu, Pendapatan Keluarga, Kecukupan Protein \& Zinc Dengan Stunting (Pendek) Pada Balita Usia 6-35 Bulan Di Kecamatan Tembalang Kota Semarang. J. Kesehat. Masy.1, 617-626 (2012).

6. Aisyah, Suyatno \& Rahfilludin, M. Z. FaktorFaktor Yang Berhubungan Dengan Stunting Pada Anak Kelas Satu Di Sdi Taqwiyatul Wathon, Daerah Pesisir Kota Semarang. J. Kesehat. Masy.7, 280-288 (2019).

7. Farah Okky Aridiyah, Ninna Rohmawati, M. R. Faktor-faktor yang Mempengaruhi Kejadian Stunting pada Anak Balita di Wilayah Pedesaan dan Perkotaan (The Factors Affecting Stunting on Toddlers in Rural and Urban Areas). e-Jurnal Pustaka Kesehat.3, 1809-1817 (2015).

8. Anisa, P. Faktor-Faktor yang Berhubungan dengan Kejadian Stunting Pada Balita Usia 2560 Bulan di Kelurahan Kalibaru Depok Tahun 2012. Univ. Indones. 1-125 (2012).

9. Olsa, E. D., Sulastri, D. \& Anas, E. Hubungan Sikap dan Pengetahuan Ibu Terhadap Kejadian Stunting pada Anak Baru Masuk Sekolah Dasar di Kecamanatan Nanggalo. J. Kesehat. Andalas6, 523 (2018).

10. Destiadi, A., Nindya, T. S. \& Sumarmi, S. Riwayat Kenaikan Berat Badan Sebagai Faktor Risiko Kejadian Stunting Pada Anak Usia 3 - 5 Tahun. Media Gizi Indones.10, 71-75 (2015).

11. Masrul, M. Gambaran Pola Asuh Psikososial Anak Stunting dan Anak Normal di Wilayah Lokus Stunting Kabupaten Pasaman dan Pasaman Barat Sumatera Barat. J. Kesehat. Andalas8, 112 (2019).

12. Ningrum, E. W. \& Utami, T. Hubungan Antara Status Gizi Stunting Dan Perkembangan Balita Usia 12-59 Bulan. J. Bidan5, 70-79 (2017).

13. Wellina, W. F., Kartasurya, M. I. \& Rahfilludin, M. Z. Faktor Risiko Stunting pada Anak Usia 6 12 Bulan. J. Gizi Indones.5, 55-61 (2016).

14. Kusuma, K. E. \& Nuryanto. Faktor Risiko Kejadian Stunting pada Anak Usia 2-3 Tahun. J. Nutr. Coll.2, 523-530 (2013). 
15. Fitri, L. Hubungan Bblr Dan Asi Ekslusif Dengan Kejadian Stunting Di Puskesmas Lima Puluh Pekanbaru. J. Endur.3,131 (2018).

16. Dasantos, Tamara Putri. Hubungan Berat Badan
Lahir Dan Panjang Badan Lahir Dengan Kejadian Stunting Pada Balita Di Kabupaten Pidie.Univ. Syiah Kuala (2019) 